\title{
Amaranthus spinosus L. Inhibits Spontaneous and Dexamethasone-Induced Apoptosis in Murine Primary Splenocytes
}

\author{
JIN-YUARN LIN ${ }^{1 *}$, CHIA-YUAN LI ${ }^{1}$ AND BI-FONG LIN ${ }^{2 *}$ \\ 1. Department of Food Science and Biotechnology, National Chung Hsing University, Taichung, Taiwan (R.O.C.) \\ 2. Department of Biochemical Science and Technology, National Taiwan University, Taipei, Taiwan (R.O.C.)
}

(Received: October 12, 2007; Accepted: December 5, 2007)

\begin{abstract}
Amaranthus spinosus L. (thorny amaranth) is traditionally selected to be an anti-diabetic herb in Taiwan. This study assessed the immuno-modulatory effects of wild A. spinosus water extract (WASWE) on spontaneous and dexamethasone (DEX)-induced apoptosis in murine primary splenocytes. The cultured splenocytes treated with WASWE products were harvested and analyzed to assess their apoptotic status according to DNA fragmentation by flow cytometry and agarose gel electrophoresis. The results showed WASWE inhibited the spontaneous and DEX-induced apoptosis of splenocytes. Furthermore, both WASWE and its activated charcoal-treated sample administered at concentration of $1.250 \mathrm{mg} / \mathrm{mL}$ inhibited intracellular protein levels of p53 (an apoptotic inducer protein) and p80 (a form of tumor necrosis factor (TNF) receptor), which are involved in apoptosis. The present study suggested the existence of a heat-labile anti-apoptotic component with high molecular weight in WASWE.
\end{abstract}

Key words: murine primary splenocytes, wild Amaranthus spinosus water extract (WASWE), anti-apoptosis, DNA fragmentation, medicinal vegetables

\section{INTRODUCTION}

Apoptosis, also known as programmed cell death (PCD), is a process by which cells undergo a form of nonnecrotic cellular suicide ${ }^{(1)}$. A key feature of apoptosis is that cells undergoing this programmed form of death are recognized by phagocytes and ingested while still intact, protecting tissues from the potentially harmful consequences of exposure to the contents of the dying cells ${ }^{(2,3)}$. The ladder type DNA fragmentation in size multiples of 180 200 base pairs seems to be the most prominent characteristic in apoptotic cells ${ }^{(4)}$. In the aged, burn injury, and chronic restraint stress, the progressive loss of organ mass could be induced by either decreased cell proliferation or increased apoptotic cell death ${ }^{(5-7)}$. Pro-inflammatory cytokines such as tumor necrosis factor (TNF)- $\alpha$ were also reported to induce apoptosis in immune cells ${ }^{(8)}$. The glucocorticoid induced apoptosis in thymocytes and was suggested through endogenous endonuclease activation $^{(9)}$. Recently the glucocorticoid dexamethasone (DEX) is found to inhibit plasmacytoid dendritic cell differentiation and increase the apoptotic death ${ }^{(10)}$.

\footnotetext{
* Author for correspondence.

Tel: +886-4-2285-1857; Fax: +886-4-2285-1857(J.-Y. Lin);

Tel: +886-2-3366-4451; Fax: +886-2-2362-1301(B.-F. Lin);

E-mail: jinlin@nchu.edu.tw (J.-Y. Lin);

E-mail: bifong@ntu.edu.tw (B.-F. Lin)
}

Apoptotic cell death, although it prevents healthy cell damage, is involved in many degenerative diseases such as neurodegenerative diseases, including Alzheimer's and Parkinson' s ${ }^{(11)}$, and neuromuscular diseases $^{(12)}$. Thus, anti-apoptotic therapy in some cases, especially in normal immune cells, might be beneficial for the corresponding human diseases ${ }^{(11-12)}$. To protect normal cells from damage due to apoptosis, natural food components have been screened to inhibit cell or tissue apoptosis. A novel proanthocyanidin IH636 grape seed extract was found to increase in vivo $\mathrm{Bcl}-\mathrm{X}_{\mathrm{L}}$ expression and prevented acetaminophen-induced programmed and unprogrammed cell death in mouse livers ${ }^{(13)}$. Phenolics including ellagic acid (EA), caffeic acid (CA) and ferulic acid (FA) exhibit anti-apoptotic activity through the Bcl-2 independent mechanism in normal human peripheral blood mononuclear cells ${ }^{(14)}$. The pre-treatment with green tea polyphenols obviously inhibits hepatocellular apoptosis and up-regulates $\mathrm{Bcl}-2$ protein expression in microcystin-LR-treated mice ${ }^{(15)}$. Intraperitoneal administration of caffeic acid phenethyl ester (CAPE), a component of honeybee propolis, reduces diffuse apoptosis in glandular epithelium and stromal cells in endometrial tissues of rats treated with fluoride ${ }^{(16)}$. Different components such as glycoprotein isolated from Solanum nigrum $\mathrm{L}^{(17)}$ and ginseng saponin ${ }^{(18)}$ induce apoptosis in HT-29 
cells and human hepatocellular carcinoma cells, recpectively. Food or herb-derived components seem to provide an anti-apoptotic possibility of normal cells.

Amaranthus spinosus L. (thorny amaranth), a plant that grows in the wild fields of Taiwan, serves extensively served as Chinese traditional medicine or wild vegetables to treat diabetes. The water extract from $A$. spinosus has been found to have a low toxicity and to demonstrate an in vivo anti-malarial activity in mice ${ }^{(19)}$. We previously found that wild $A$. spinosus water extract (WASWE) exerted immuno-stimulating effects via activating $B$ lymphocytes and subsequent $T$ cell proliferation in vitro ${ }^{(20)}$. In this study WASWE was further applied to primary murine splenocyte cultures to characterize its anti-apoptotic properties.

\section{MATERIALS AND METHODS}

\section{Preparation of WASWE}

The WASWE was prepared as described by Lin et $a l .{ }^{(20)}$. Briefly, fresh leaves of $A$. spinosus, which were collected in summer from central areas in Taiwan, were weighed and chopped. Added to the same weight of deionized water, the sample was stirred in a Waring blender to extract the water-soluble constituents. The slurry was then centrifuged at $9,000 \times \mathrm{g}\left(4^{\circ} \mathrm{C}\right)$ for $30 \mathrm{~min}$. The supernatant was directly lyophilized to obtain a crude WASWE powder and the final yield was about $4.7 \%$ (g powder per $100 \mathrm{~g}$ of fresh leaves). Part of the supernatant was heated at $100^{\circ} \mathrm{C}$ for $30 \mathrm{~min}$ and then lyophilized to harvest the heat-treated WASWE powder. Part of the crude WASWE powder was dissolved in deionized water and then slowly mixed with activated charcoal $(1: 1, \mathrm{w} /$ w) to absorb small WASWE molecules. After standing at $4^{\circ} \mathrm{C}$ for $30 \mathrm{~min}$, the mixture was filtered with filter paper. The supernatant was lyophilized to obtain activated charcoal-treated WASWE powder.

\section{Experimental Animals for Primary Splenocytes}

BALB/c mice (female, adult) were from the Laboratory Animal Center, College of Medicine, National Taiwan University and maintained in the Department of Biochemical Science and Technology, College of Life Science, National Taiwan University, and the Department of Food Science and Biotechnology at National Chung Hsing University, College of Agriculture and Natural Resources in Taichung, Taiwan, ROC. The mice were housed and fed a standard lab diet (normal chow diet). The animal room was kept on a 12-h-light and 12-h-dark cycle. Constant temperature $\left(25 \pm 2^{\circ} \mathrm{C}\right)$ and humidity were maintained. The animals (8- to 10 -weeks old) were sacrificed using $\mathrm{CO}_{2}$ inhalation to obtain spleens. The abdominal cavities were opened aseptically and the spleens were removed.

\section{Primary Splenocyte Cultures}

The primary splenocyte culture preparation and assay of in vitro apoptosis using WASWE were manipulated as described by Lin et al. ${ }^{(20)}$. Spleens were removed aseptically from adult BALB/c mice. Single spleen cells were prepared by lysing the red blood cells. Splenocytes were isolated from each animal and adjusted to $2 \times 10^{6}$ cells $/ \mathrm{mL}$ in TCM (a defined commercial serum replacement, Celox Laboratories Inc.) medium $[10 \mathrm{~mL}$ of TCM, $500 \mathrm{~mL}$ of RPMI 1640 medium (Atlanta biologicals, $\mathrm{M} 30115$ ), and $2.5 \mathrm{~mL}$ of antibiotic-antimycotic solution $(100 \times)$ containing 10,000 units $/ \mathrm{mL}$ of penicillin, 10,000 $\mu \mathrm{g} / \mathrm{mL}$ of streptomycin, and $25 \mu \mathrm{g} / \mathrm{mL}$ of amphotericin B in $0.85 \%$ saline (Atlanta Biologicals, B22110)]. Splenocytes $(0.5 \mathrm{~mL} /$ well $)$ with WASWE $(0.5 \mathrm{~mL} /$ well; $0,0.250$, $0.500,1.250$, or $2.500 \mathrm{mg} / \mathrm{mL}$ in TCM medium, respectively) were plated in 24 well plates. The plates were incubated at $37^{\circ} \mathrm{C}$ in a humidified incubator with $5 \% \mathrm{CO}_{2}$ and $95 \%$ air for various time $(0,6,12,24,48$, or $72 \mathrm{~h})$. The cells were collected and assayed for the nuclear DNA cell-cycle phase distribution. The viable cells in each case were counted in haemocytometer using trypan blue exclusion staining.

\section{Cell Cycle Analysis by Flowcytometry}

To determine the cell-cycle phase distribution of nuclear DNA ${ }^{(21-22)}$, primary splenocytes $\left(2 \times 10^{6}\right.$ cells/ $\mathrm{mL}, 0.5 \mathrm{~mL} /$ well) from female BALB/c mice exposed to WASWE $(0.5 \mathrm{~mL} /$ well $)$ for various times $(0,6,12,24,48$, or $72 \mathrm{~h}$ ) were individually collected into a $1.5 \mathrm{~mL}$ microcentrifuge tube. The cells were harvested by centrifugation at $400 \times g$ for $10 \mathrm{~min}$ and washed twice in ice cold phosphate-buffered saline (PBS, $137 \mathrm{mM} \mathrm{NaCl}, 2.7 \mathrm{mM}$ $\mathrm{KCl}, 8.1 \mathrm{mM} \mathrm{Na}_{2} \mathrm{HPO}_{4}, 1.5 \mathrm{mM} \mathrm{KH}_{2} \mathrm{PO}_{4}, \mathrm{pH}$ 7.2-7.4, 0.2 $\mu \mathrm{m}$ filtered). The cell pellet was re-suspended in $0.4 \mathrm{~mL}$ of PBS, and then fixed with $0.4 \mathrm{~mL}$ of cold $\left(-20^{\circ} \mathrm{C}\right)$ absolute ethanol for $30 \mathrm{~min}$ by thorough and slow mixing. The fixed cells were spun down at 3,000 $\times g$ for $10 \mathrm{~min}$ and then $10,000 \times g$ for $1 \mathrm{~min}$. The cell pellet was washed with PBS once. Then, the cell pellet was vortexed and incubated with $100 \mu \mathrm{L}$ of RNase A solution $(100 \mu \mathrm{g} / \mathrm{mL}$ PBS) at $37^{\circ} \mathrm{C}$ for $30 \mathrm{~min}$. The nuclear DNA of splenocytes was labeled with $100 \mu \mathrm{L}$ of propidium iodide (PI, $10 \mu \mathrm{g} / \mathrm{mL}$ PBS, Sigma P4170) at $4^{\circ} \mathrm{C}$ for $15 \mathrm{~min}$. Finally, the nuclear DNA cell-cycle phase distribution was determined using a FACScan flow cytometer (Becton Deckinson, CA). Cell Quest software (Becton Deckinson, CA, USA) was run for data acquisition and analysis. Fluorescence detector (FL2-A) for PI was equipped with 488 $\mathrm{nm}$ argon laser light source and $623 \mathrm{~nm}$ band pass filter (linear scale, Becton Deckinson). Total 10,000 events were acquired for analysis. Histograms are displayed with DNA content (x-axis, PI-fluoresence) versus cell counts (y-axis). The apoptotic cell content is the percentage of cells with subG ${ }_{1}$ DNA content. 
V. Analysis of DNA Fragmentation by Agarose Gel Electrophoresis

To assay the effects of WASWE administration on splenocyte DNA fragmentation due to apoptosis, the DNA fragmentation pattern (DNA ladder) was analyzed by $1.5 \%$ agarose gel electrophoresis ${ }^{(21,23)}$. Splenocytes $\left(6 \times 10^{6}\right.$ cells) incubated without and with WASWE $(1.250 \mathrm{mg} / \mathrm{mL})$

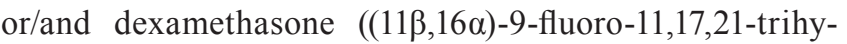
droxy-16-methyl-pregna-1,4-diene-3,20-dione, DEX, $10^{-7}$ $\mathrm{M}$, an apoptosis-inducing reagent) for various time $(0,18$, 24,48 , or $72 \mathrm{~h}$ ) were individually collected by centrifugation at $200 \times g$ for $10 \mathrm{~min}$ and then washed with PBS twice. The cell pellets were treated with $0.5 \mathrm{~mL}$ of lysis buffer (10 mM Tris-HCl, pH 7.4, 10 mM EDTA, 0.2\% Triton X100) for $10 \mathrm{~min}$ at room temperature. After centrifugation at $10,000 \times g, 4^{\circ} \mathrm{C}$ for $10 \mathrm{~min}$, the supernatant was incubated with proteinase $\mathrm{K}(100 \mu \mathrm{g} / \mathrm{mL})$ at $50^{\circ} \mathrm{C}$ overnight. The DNA in lysed solution was extracted using chloroform/phenol (1:1) and precipitated with equal volume of $\mathrm{NaCl}(500 \mathrm{mM})$ and isopropanol at $-20^{\circ} \mathrm{C}$ overnight. DNA was collected by centrifugation at $14,000 \times g$ and $0^{\circ} \mathrm{C}$ for $30 \mathrm{~min}$. The DNA pellet was repeatedly washed with $70 \%$ ethanol and collected by centrifugation at $14,000 \times g$ and $0^{\circ} \mathrm{C}$ for $10 \mathrm{~min}$. The DNA was dissolved in $100 \mu \mathrm{L}$ of TE buffer (10 mM Tris, $\mathrm{pH}$ 7.5, $1 \mathrm{mM}$ EDTA) and incubated with $1 \mu \mathrm{g} / \mathrm{mL}$ of RNase A for another $1 \mathrm{~h}$ at $37^{\circ} \mathrm{C}$. Horizontal electrophoresis was performed and DNA (500 ng) was loaded over a $1.5 \%$ agarose gel. The bands were visualized using ethidium bromide staining under UV illumination. Photographic negatives were scanned and quantified with a Microcomputer Imaging Device (MCID-M4 3.0; Imaging Research Inc., Ontario, Canada) and associated software ${ }^{(24)}$. The DNA fragmentation level was expressed as relative density (D) $\times$ area (A) of small DNA fragment bands ( $<800 \mathrm{bps})$ to total DNA in each lane.

\section{Analysis of Possible Pro-apoptotic and Anti-apoptotic} Protein Expressions

Splenocytes were cultured without or with WASWE

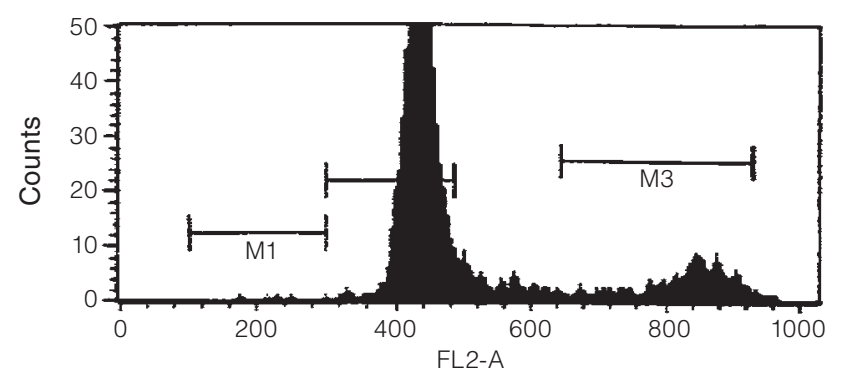

(A) $0 \mathrm{hr}$, control as indicated and lysed on ice for 30 min with $200 \mu \mathrm{L}$ of an extraction buffer containing $10 \mathrm{mM}$ Tris ( $\mathrm{pH}$ 7.2), 150 $\mathrm{mM} \mathrm{NaCl}, 1 \%$ Triton X-100, $5 \mathrm{mM}$ EDTA, $1 \mathrm{mM}$ sodium orthovanadate, $100 \mathrm{mg} / \mathrm{mL}$ phenylmethylsulfonyl fluoride (PMSF), and $0.225 \mathrm{U} / \mathrm{mL}$ aprotinin ${ }^{(25)}$. After centrifugation at $16,000 \times g$ for $20 \mathrm{~min}$ at $4^{\circ} \mathrm{C}$, the supernatants were collected and mixed with SDS-PAGE sample buffer containing 2-mercaptoethanol. The protein concentration was determined using BCA (Bicinchonic acid) protein assay reagent kit (Pierce 23227) and the protein concentration from each individual treatment was adjusted to the same. Aliquots of $10 \mu \mathrm{L}$ from each cell lysate were analyzed by SDS-PAGE electrophoresis in a $12.5 \%$ polyacrylamide gel containing $0.1 \%$ SDS using a Mini-PROTEIN II cell (Bio-Rad Laboratories). The electrophoresis was carried out at $110 \mathrm{~V}, 30 \mathrm{~mA}$ for about $1.5 \mathrm{~h}$. The gels were then stained with commassie brilliant blue R stain.

\section{Statistical Analysis}

Data were analyzed by the Windows SAS program (Version 6.12). Data are expressed as mean \pm S.D. and analyzed statistically using ANOVA followed, if justified by the statistical probability $(P<0.05)$, by Duncan's New Multiple Range test or unpaired Student's t-test. Differences were considered statistically significant if $P<0.05$.

\section{RESULTS}

\section{Effects of WASWE Administration on Spontaneous Apoptosis of Primary Splenocytes from BALB/c Mice}

To evaluate the effects of WASWE on the spontaneous apoptosis of splenocytes from female BALB/c mice, the splenocytes were co-incubated with various concentrations of WASWE for the period of the $72 \mathrm{~h}$. The apoptosis rate and viable cell number were measured by the FACS and trypan blue methods, respectively. Figure 1 shows the effects of WASWE administration on mouse splenic cell cycle regulation incubated at $37^{\circ} \mathrm{C}$ for $72 \mathrm{~h}$. Splenocyte

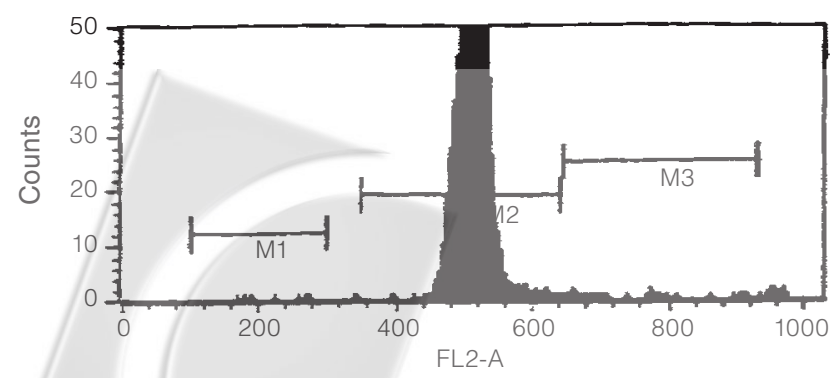

(a) $0 \mathrm{hr}, 1.25 \mathrm{mg} / \mathrm{mL}$

Figure 1. Effects of WASWE administration on mouse splenic cell cycle regulation incubated at $37^{\circ} \mathrm{C}$ for $72 \mathrm{~h}$. Splenocyte cultures without or with WASWE $(1.250 \mathrm{mg} / \mathrm{mL})$ were incubated and harvested at the indicated times $0,6,12,24,48$, and $72 \mathrm{~h}$, and cell cycle phase distribution of nuclear DNA was determined by flow cytometry using PI as DNA-binding fluorochrome. Histograms display DNA content (x-axis, PI-fluorescence) vs. counts (y-axis). M1: apoptotic cells. M2: live cells. M3: proliferating or aggregated cells. 


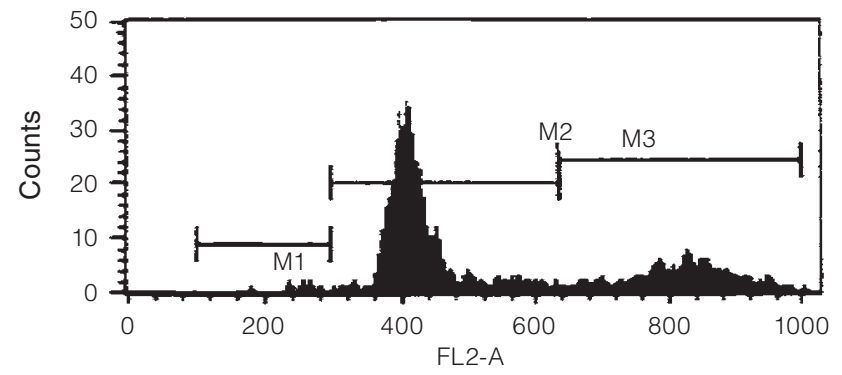

(B) $6 \mathrm{hr}$, control

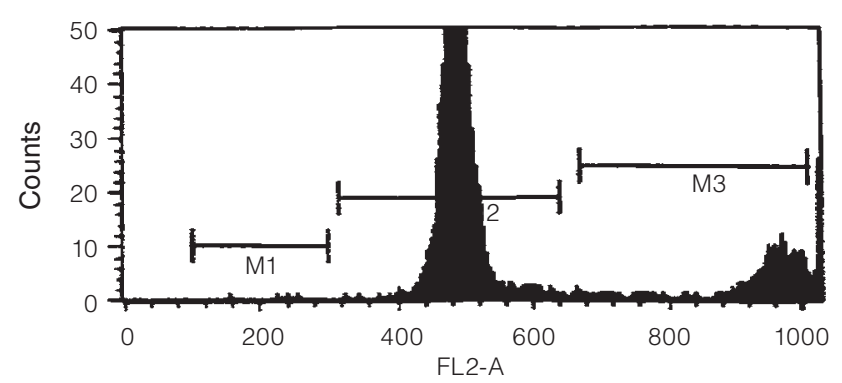

(C) $12 \mathrm{hr}$, control

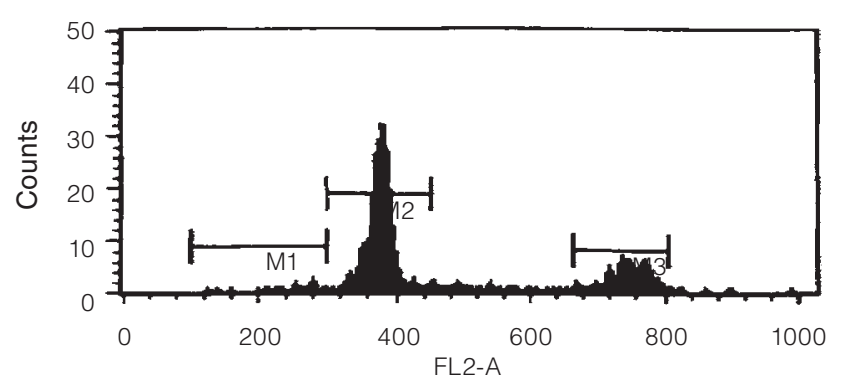

(D) $24 \mathrm{hr}$, control

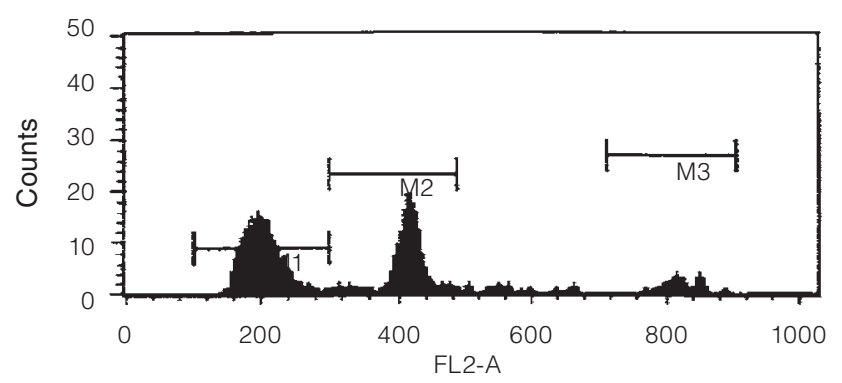

(E) $48 \mathrm{hr}$, control

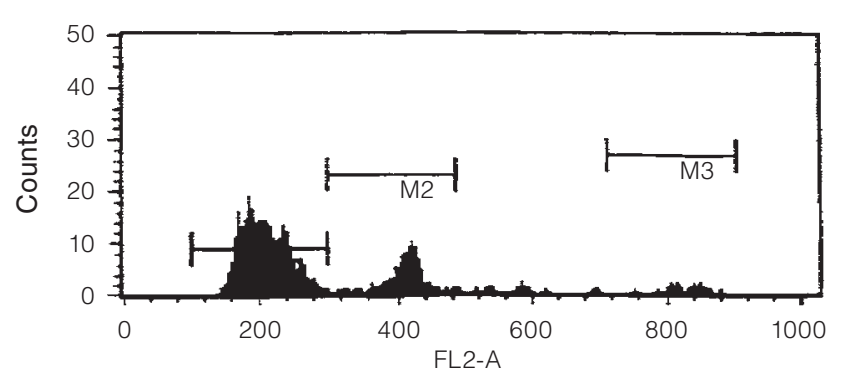

(F) $72 \mathrm{hr}$, control

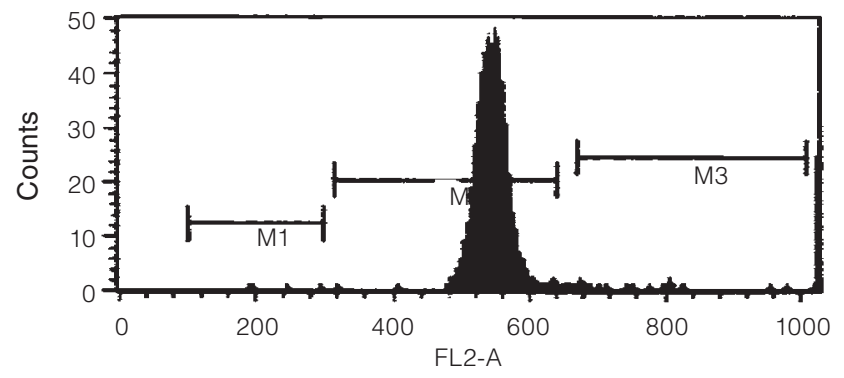

(b) $6 \mathrm{hr}, 1.25 \mathrm{mg} / \mathrm{mL}$

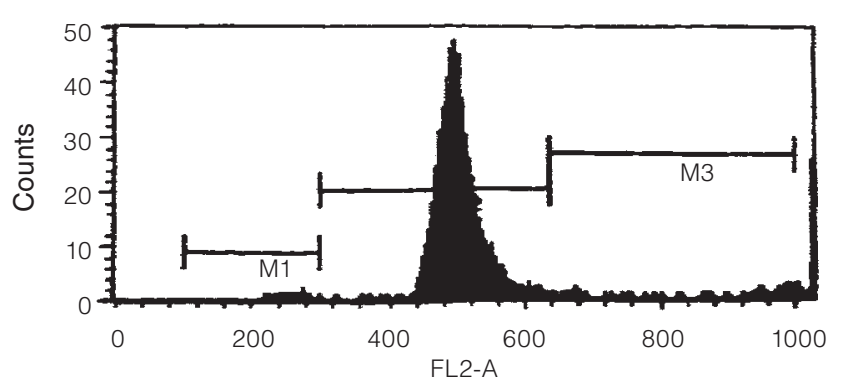

(c) $12 \mathrm{hr}, 1.25 \mathrm{mg} / \mathrm{mL}$

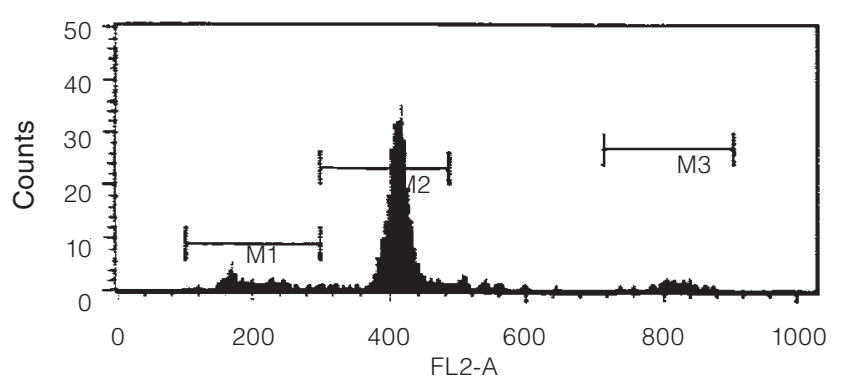

(d) $24 \mathrm{hr}, 1.25 \mathrm{mg} / \mathrm{mL}$

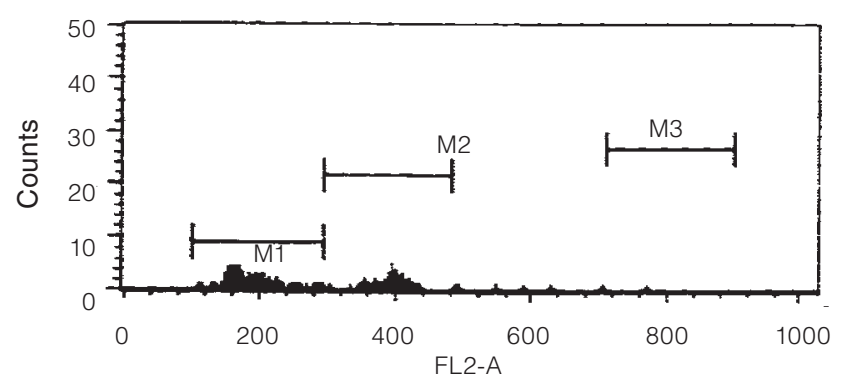

(e) $48 \mathrm{hr}, 1.25 \mathrm{mg} / \mathrm{mL}$

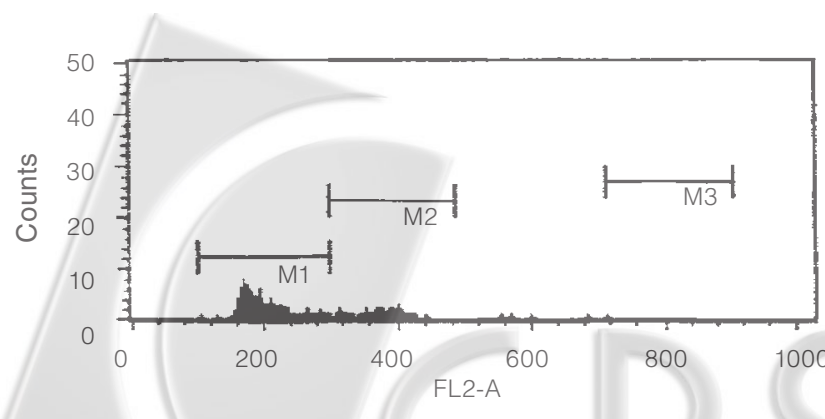

(f) $72 \mathrm{hr}, 1.25 \mathrm{mg} / \mathrm{mL}$

Figure 1. Continued 
cultures without or with WASWE at the indicated concentration of $1.250 \mathrm{mg} / \mathrm{mL}$ were incubated and harvested at the indicated time intervals of $0,6,12,24,48$, and $72 \mathrm{~h}$, and cell cycle phase distribution of nuclear DNA was determined by flow cytometry using PI as DNA-binding fluorochrome. Histograms were displayed with DNA content ( $\mathrm{x}-$ axis, PI-fluorescence) vs. counts (y-axis). M1, M2, and M3 respectively represent the changes in apoptotic cells, live cells, and proliferating or aggregated cells. The results showed that apoptotic cell counts (M1) increased as the incubation time extended. However, WASWE administration at the indicated concentration inhibited spontaneous apoptosis of primary splenocytes during $72 \mathrm{~h}$ incubation. To demonstrate the differences of splenic cell apoptosis after WASWE administration, the spontaneous apoptosis at various incubation time and various WASWE concentrations used was further compared. Figure 2 showed that all concentrations of WASWE administration $(0.125$, $0.250,0.625$, and $1.250 \mathrm{mg} / \mathrm{mL}$ ) significantly inhibited the spontaneous primary splenocyte apoptosis in a dosedependent manner for $72 \mathrm{~h}$ in vitro incubation. The spontaneous apoptotic control cells reached more than $25 \%$ for $72 \mathrm{~h}$ incubation, whereas the apoptosis of splenocytes treated with WASWE significantly decreased.

II. Inter-changes Between Percentage of Spontaneous Apoptotic Cells and Viable Cell Number of Splenocytes Administrated with Various Concentrations of WASWE

To clarify the correlation between anti-apoptotic and proliferated cells, inter-changes between $\%$ of apoptotic

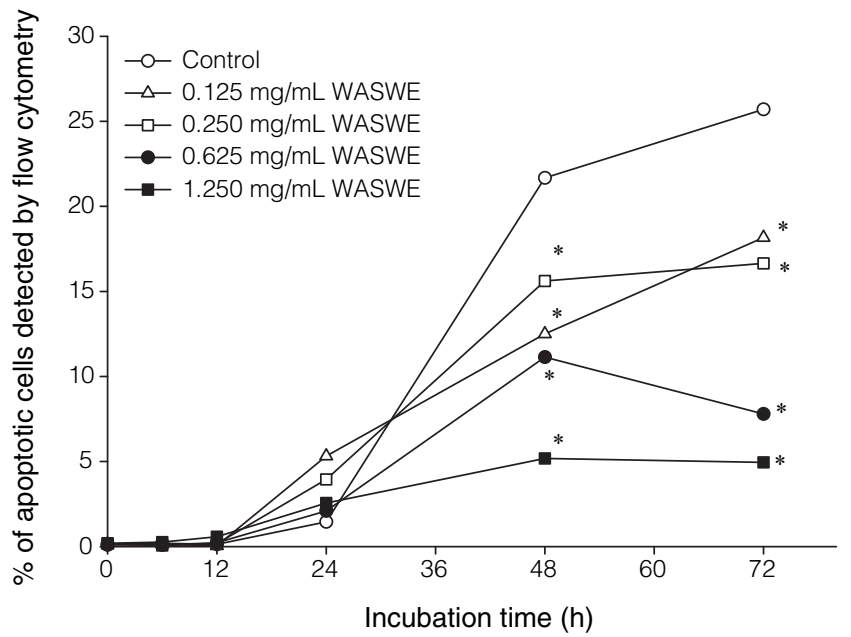

Figure 2. Effects of WASWE administration at the indicated concentrations on spontaneous apoptotsis of mouse splenocytes incubated at $37^{\circ} \mathrm{C}$ for $72 \mathrm{~h}$. The $\%$ of apoptotic cells of each point calculated from cytometry represents the mean value $(n=2)$. The original cell density was $1 \times 10^{6}$ cells $/ \mathrm{mL}$. Data are assayed using unpaired Student's $t$-test. Asterisk $(*)$ means significantly different $(P$ $<0.05$ ) from the control at the same experimental point through 48 or $72 \mathrm{~h}$ incubation. cells and viable cell number were depicted as Figure 3 Figure 3(A) showed that apoptotic percentage and viable cell number of splenocytes were affected by WASWE in a dose-dependent manner. The WASWE concentration at the $1.250 \mathrm{mg} / \mathrm{mL}$ exerted a maximum activity against spontaneous apoptosis of splenocytes. However, a reverse correlation was shown to exist between apoptotic and viable cell numbers. Real apoptotic cell numbers at the indicated concentrations of WASWE administration were obtained from $\%$ of apoptotic cells $\times$ viable cell number, and the results were shown in Figure 3(B). The results showed that real apoptotic cell numbers of splenocytes were decreased by WASWE in a dose-dependent manner. The real apoptotic cell numbers were decreased from $20.6 \times 10^{4}$ to $6.68 \times 10^{4}$. The results suggested that WASWE administration indeed inhibit spontaneous apoptosis of splenocyte in vitro especially at the indicated concentration of $1.250 \mathrm{mg} / \mathrm{mL}$.
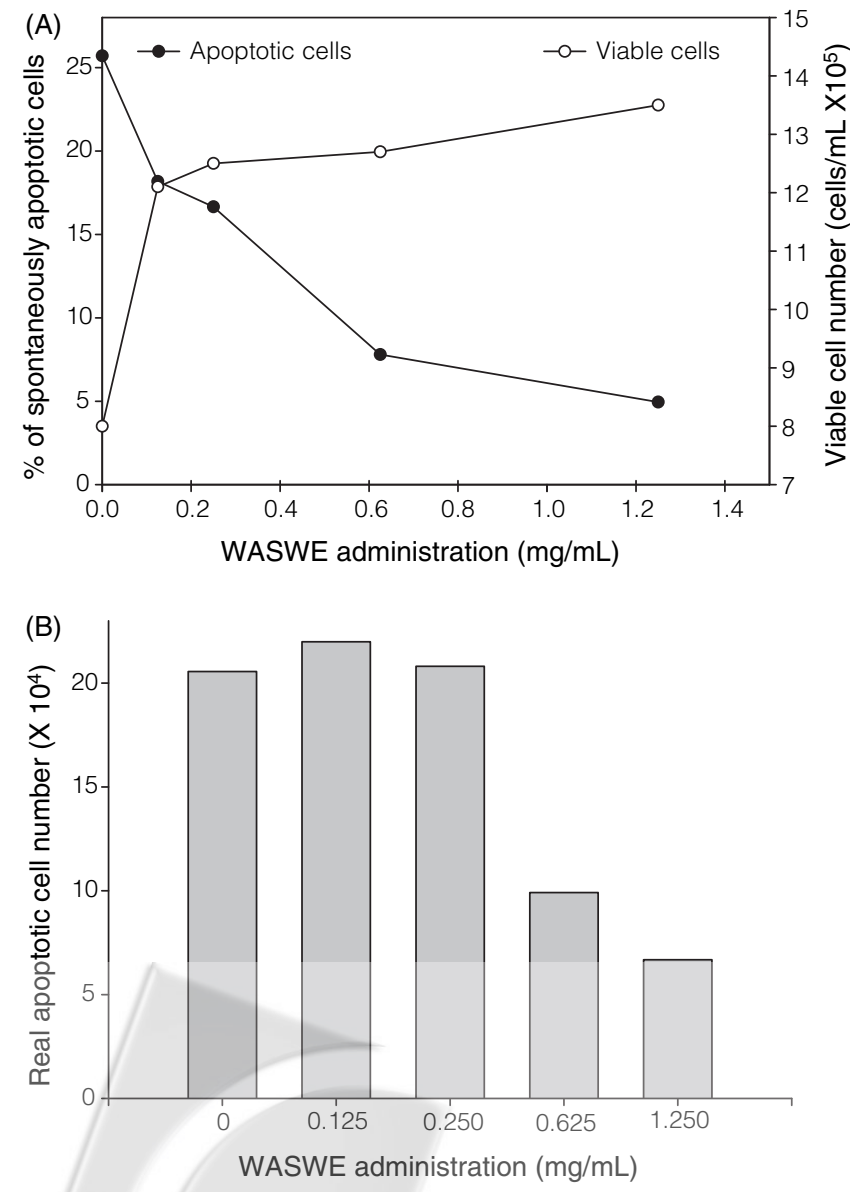

Figure 3. Inter-changes between $\%$ of apoptotic cells and viable cell numbers (A) and real apoptotic cell number (B) of splenocytes administrated with different concentrations of WASWE incubated at $37^{\circ} \mathrm{C}$ for $72 \mathrm{~h}$. The real apoptotic cell number was obtained from $\%$ of apoptotic cells $\times$ viable cell number. The original cell density was $1 \times$ $10^{6}$ cells $/ \mathrm{mL}$. Each point calculated from flow cytometry and trypan blue exclusion method represents the mean value $(n=2)$. 

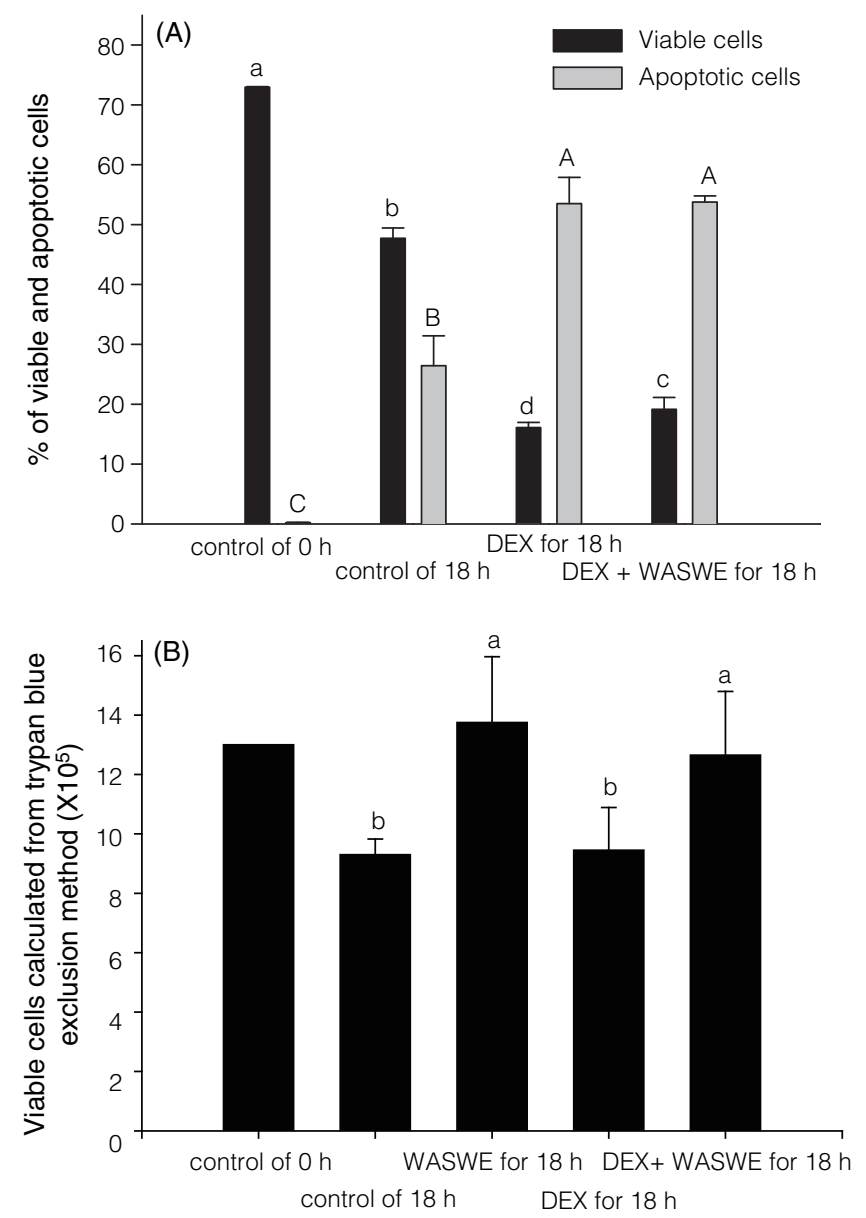

Treatments

Figure 4. Viable and apoptotic cells in splenocytes cultured in the absence or presence with dexamethasone (DEX, $\left.1 \times 10^{-7} \mathrm{M}\right)$ and incubated without or with WASWE $(1.250 \mathrm{mg} / \mathrm{mL})$ for $18 \mathrm{~h}$ and respectively detected by flow cytometry (A) and trypan blue exclusion method (B). The original cell density was $1.3 \times 10^{6}$ cells/ $\mathrm{mL}$. Each bar represents the mean value $+/-\mathrm{SD}(\mathrm{n}=4)$. Within each graph bars not sharing a minuscule letter or capital letter, respectively, are significantly different $(P<0.05)$ from each other according to Duncan's New Multiple Range test.

\section{Effects of WASWE Administration on Dexamethasone- induced Apoptosis of Primary Murine Splenocytes}

To further elucidate the effects of WASWE administration on glucocorticoid-induced apoptosis, dexamethasone (DEX, $\left.1 \times 10^{7} \mathrm{M}\right)$ in the absence or presence of WASWE $(1.250 \mathrm{mg} / \mathrm{mL})$ was administrated to splenocyte cultures for $18 \mathrm{~h}$. Splenocytes were detected by flow cytometry and trypan blue exclusion method. Figure 4 shows viable and apoptotic cells in splenocytes cultured in the absence or presence of DEX and incubated without or with WASWE $(1.250 \mathrm{mg} / \mathrm{mL})$ for $18 \mathrm{~h}$. The results showed that antagonistic effects of WASWE and DEX existed between apoptotic (M1) and live cell (M2) rates (Figure 4(A)). The results showed that apoptotic cells (M1) increased, whereas live cells (M2) decreased significantly as the incubation time lengthened to $18 \mathrm{~h}$. DEX $\left(1 \times 10^{7}\right.$ $\mathrm{M})$ treatment for $18 \mathrm{~h}$ significantly induced apoptosis and decreased live cells in splenocyte cultures (Figure 4(A)). To avoid the confounding of percentage expression, viable cells were also calculated by trypan blue exclusion method (Figure 4(B)). The results showed that WASWE administration significantly $(P<0.05)$ increased spontaneous and DEX-treated viable cells at the incubation of $18 \mathrm{~h}$.

\section{Effects of WASWE Administration on Spontaneous or Dexamethasone-induced DNA Fragmentation of Primary Murine Splenocytes}

Spontaneous or dexamethasone-induced splenocyte cultures treated with WASWE at $1.250 \mathrm{mg} / \mathrm{mL}$ for 72 $\mathrm{h}$ were assayed to further clarify the effects of WASWE administration on DNA fragmentation due to apoptosis. DNA was extracted and electrophoresis was carried out in a $1.5 \%$ agarose gel. Figure 5 shows the effects of WASWE administration on DNA fragmentation due to spontaneous and DEX-induced apoptosis. The DNA isolated from spontaneous (control) and DEX-treated splenocytes exhibited a ladder pattern of DNA fragments with size multiples of 180 200 base pair units (bps), as displayed in lanes 2 12 of Figure 5. The DNA ladders from splenocyte cultures

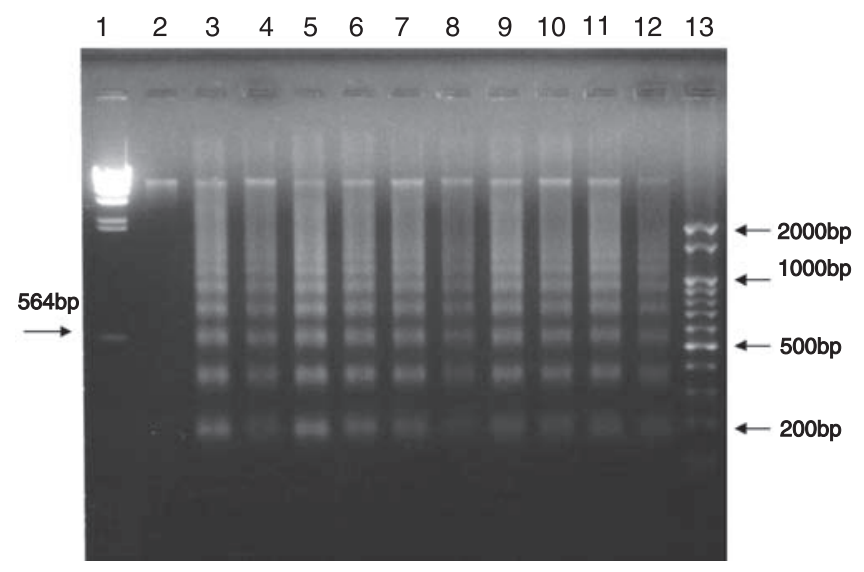

Figure 5. Spontaneous or dexamethasone-induced DNA fragmentation in mouse splenocytes treated with WASWE at the indicated concentration of $1.250 \mathrm{mg} / \mathrm{mL}$ for different incubation time. DNA was extracted and electrophoresis was carried out in $1.5 \%$ agarose gel. lane 1: $\lambda$ DNA/Hind III marker, lane 2: spontaneous DNA fragmentation for $0 \mathrm{~h}$ incubation, lane 3: spontaneous DNA fragmentation for $18 \mathrm{~h}$ incubation, lane 4: DNA fragmentation cultured with WASWE for $18 \mathrm{~h}$, lane 5: DNA fragmentation cultured with dexamethasone $\left(1 \times 10^{-7} \mathrm{M}\right)$ for $18 \mathrm{~h}$, lane 6: DNA fragmentation cultured with dexamethasone and WASWE for 18 h, lane 7: spontaneous DNA fragmentation for $24 \mathrm{~h}$ incubation, lane 8: DNA fragmentation cultured with WASWE for $24 \mathrm{~h}$, lane 9: spontaneous DNA fragmentation for $48 \mathrm{~h}$ incubation, lane10: DNA fragmentation cultured with WASWE for $48 \mathrm{~h}$, lane 11: spontaneous DNA fragmentation for $72 \mathrm{~h}$ incubation, lane 12: DNA fragmentation cultured with WASWE for $72 \mathrm{~h}$, lane 13: 100 bp DNA ladder marker. 
due to apoptosis were obvious for $72 \mathrm{~h}$ incubation. Quantitative measurements of DNA fragmentation were further performed using a microcomputer imaging device (MCID). The quantitative apoptotic levels based on DNA fragmentation from 180 200 bps (bottom band 1 in lanes 2 12) of Figure 5 is shown as Table 1 . Table 1 shows desitometric profiles of DNA distribution in spontaneous and DEXtreated splenocytes derived from photographic negatives of the gel in Figure 5. There was apparent in general shift in density and area from regions of high to low molecular weight in the treated cells. The DNA fragmentation was negligible in the control of $0 \mathrm{~h}$ and merely $1.27 \%$ (Figure 5 lane 2). After $18 \mathrm{~h}$ incubation, spontaneous DNA fragmentation increased to the level of $4.78 \%$ (Figure 5 lane 3). However, WASWE administration lowered the DNA fragmentation level to $1.17 \%$ (Figure 5 lane 4). After $24 \mathrm{~h}$ incubation, spontaneous DNA fragmentation increased to the level of $2.87 \%$ (lane 7); whereas WASWE administra-

Table 1. Quantitative apoptotic levels based on 180-200 bps of DNA laddering fragments from administrated splenocytes of Figure 5

\begin{tabular}{|c|c|c|c|}
\hline lanes & bands $^{\mathrm{a}}$ & $\mathrm{D} \times \mathrm{A}^{\mathrm{b}}$ & $\begin{array}{c}\text { DNA } \\
\text { fragmentation } \\
(\%)^{\mathrm{c}}\end{array}$ \\
\hline Lane 2, & band 1 & 2 & 1.27 \\
\hline control of $0 \mathrm{~h}$ & total & 197 & \\
\hline Lane 3, & band 1 & 34 & 4.78 \\
\hline control of $18 \mathrm{~h}$ & total & 721 & \\
\hline Lane 4, & band 1 & 6 & 1.17 \\
\hline WASWE for $18 \mathrm{~h}$ & total & 537 & \\
\hline Lane 5, & band 1 & 40 & 5.21 \\
\hline DEX for $18 \mathrm{~h}$ & total & 763 & \\
\hline Lane 6 , & band 1 & 24 & 3.67 \\
\hline DEX+WASWE for $18 \mathrm{~h}$ & total & 644 & \\
\hline Lane 7, & band 1 & 18 & 2.87 \\
\hline control of $24 \mathrm{~h}$ & total & 631 & \\
\hline Lane 8 , & band 1 & 0 & 0.09 \\
\hline WASWE for $24 \mathrm{~h}$ & total & 437 & \\
\hline Lane 9 , & band 1 & 13 & 1.99 \\
\hline control of $48 \mathrm{~h}$ & total & 652 & \\
\hline Lane 10 & band 1 & 9 & 1.63 \\
\hline WASWE for $48 \mathrm{~h}$ & total & 580 & \\
\hline Lane 11, & band 1 & 8 & 1.38 \\
\hline control of $72 \mathrm{~h}$ & total & 598 & \\
\hline Lane 12 , & band 1 & 2 & 0.48 \\
\hline WASWE for $72 \mathrm{~h}$ & total & 373 & \\
\hline
\end{tabular}

aband 1: 180 200 bps; total: all the visualized bands in the same lane. ${ }^{\mathrm{b}} \mathrm{D} \times \mathrm{A}$ : density multiplies area in the gel photograph.

${ }^{\mathrm{c}} \mathrm{DNA}$ fragmentation $(\%)=((\mathrm{D} \times \mathrm{A})$ of band $1 /(\mathrm{D} \times \mathrm{A})$ of all bands in the same lane) $\times 100$. tion decreased the DNA fragmentation level to $0.09 \%$ (lane 8). Even though the primary cells might be killed through physical damage at making of single cells and malnutrition in the media during 48 72 $\mathrm{h}$ incubation (Figure 1), WASWE administration provided the protection and slightly inhibited the apoptosis-induced DNA fragmentation of splenocytes (decrease, respectively, from 1.99\% to $1.63 \%$ and from $1.38 \%$ to $0.48 \%$ ). After exposure for $18 \mathrm{~h}$, $\operatorname{DEX}\left(1 \times 10^{-7} \mathrm{M}\right)$ administration induced $5.21 \%$ of apoptosis-induced DNA fragmentation (lane 5). WASWE administration lowered the DEX-induced DNA fragmentation to $3.67 \%$ (lane 6 ). The results indicated that spontaneous or DEX-induced DNA fragmentation due to apoptosis could be inhibited by WASWE administration, especially during the first 18 $24 \mathrm{~h}$ experimental period of incubation.

\section{Effects of WASWE Products on Intracellular Protein Expression of Splenocytes}

To clarify the effects of WASWE administration on the intracellular protein expression of splenocytes, various WASWE products were incubated with splenocytes for $48 \mathrm{~h}$. The intracellular proteins were extracted and subjected to $12.5 \%$ SDS-PAGE electrophoresis analysis. The results, as shown in Figure 6, two novel intracellular proteins, with molecular weights of $53 \mathrm{kDa}$ (p53) and 80 $\mathrm{kDa}(\mathrm{p} 80)$, were obviously changed after WASWE administration (Figure 6). On the control lane, rare expressions of p53 and p 80 were observed (Figure 6 lane 1). Contrary to our expectation, the expression levels of $\mathrm{p} 53$ and $\mathrm{p} 80$ increased upon administrations with WASWE, activated charcoal- or heat-treated WASWE for $48 \mathrm{hr}$ at the indicated low concentration of $0.078 \mathrm{mg} / \mathrm{mL}$ (Figure 6 lanes 2, 3, and 4). However, the expressions of p53 and p80 decreased after administrations with WASWE and acti-

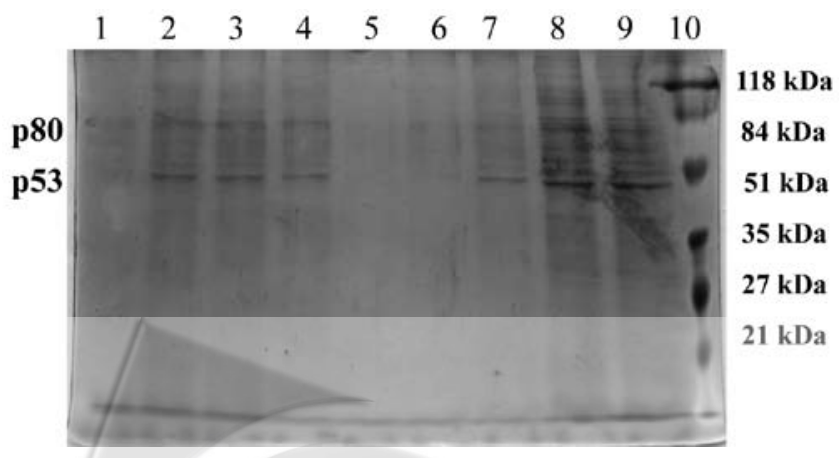

Figure 6. Effects of different WASWE products on intracellular protein expression of splenocytes incubated for $48 \mathrm{~h}$. Original cell density: $5 \times 10^{6}$ cells $/ \mathrm{mL}$. Gel: $12.5 \%$ SDS-PAGE. lane 1: control, lane 2: WASWE $(0.078 \mathrm{mg} / \mathrm{mL})$, lane 3: activated charcoal-treated WASWE $(0.078 \mathrm{mg} / \mathrm{mL})$, lane 4 : heat-treated WASWE $(0.078 \mathrm{mg} /$ $\mathrm{mL})$, lane 5: WASWE $(1.250 \mathrm{mg} / \mathrm{mL})$, lane 6: activated charcoaltreated WASWE $(1.250 \mathrm{mg} / \mathrm{mL})$, lane 7 : heat-treated WASWE $(1.250$ $\mathrm{mg} / \mathrm{mL})$, lane 8: LPS $(5 \mu \mathrm{g} / \mathrm{mL})$, lane 9: PHA $(5 \mu \mathrm{g} / \mathrm{mL})$, lane10: protein markers. 
vated charcoal-treated WASWE at the indicated high concentrations of $1.250 \mathrm{mg} / \mathrm{mL}$ (Figure 6 lanes 5, 6, and 7). A biphasic effect on intracellular expression levels of p53 and p80 existed upon administration of extremely low and high concentrations of WASWE.

\section{DISCUSSION}

Apoptosis is verified to participate in many degenerative, neurodegenerative, and neuromuscular diseases ${ }^{(11,12)}$. The present study demonstrated that WASWE administration significantly inhibited spontaneous primary splenocyte apoptosis in a dose-dependent manner in vitro (Figure 1 and Figure 2). The results further indicated that DEX-treatment for $18 \mathrm{~h}$ significantly induced apoptosis of splenocytes, but decreased viable cells in splenocyte cultures (Figure 4). However, WASWE administration significantly increased spontaneous and DEX-treated viable cells compared to those of control and DEX treatment only at the same incubation time of $18 \mathrm{~h}$ (Figure 4(B)). Chronic restraint stress results in significant increase in the expression of pro-apoptotic genes, including Fas, FADD, p53, p21, and BNIP3 (Bcl2/adenovirus E1B $19 \mathrm{kDa}$-interacting protein 3) in the spleen from restraint stressed mice ${ }^{(26)}$. Decrease in Bcl2 and increase in Fas receptor expression as well as the increased activation of caspase 8,3 , and 9 in splenocytes from aged $\mathrm{C} 57 / \mathrm{BL}$ mice were also reported ${ }^{(5)}$. Forrest $e t$ $a l .{ }^{(26)}$ have suggested that finding a target for anti-apoptotic therapy to protect splenocytes is possible. The antiapoptotic therapy in some cases such as apoptotic cell death in aging and stress might be beneficial and possible. This study suggests that WASWE exhibited in vitro anti-apoptotic potential in situations of spontaneous or glucocorticoid DEX-treated stress. It might be further applied to treat particular diseases due to unnecessary apoptosis in splenocytes. However, the effective concentration $(1.25 \mathrm{mg} / \mathrm{mL})$ used in this study was still too high. The WASWE should be further purified and unraveled its immuno-modulatory mechanism against splenocytes' apoptosis.

The ladder type DNA fragmentation in size multiples of 180 200 bps due to nuclease activation is the most prominent characteristic in apoptotic cells ${ }^{(4)}$. This report showed the effects of WASWE administration on DNA fragmentation due to spontaneous and DEX-induced apoptosis in primary murine splenocytes. Our results displayed the DNA ladders in the agarose gel. The shift in density and area from regions of high to low molecular weight in the treated cell lanes was obvious (Figure 5). Quantitative measurement of DNA fragments of 180 200 bps indicated that spontaneous or DEX-induced DNA fragmentation due to apoptosis could be inhibited by WASWE administration, especially during the first 18 $24 \mathrm{~h}$ of experimental incubation period (Table 1). The results suggest that WASWE might have direct or indi- rect inhibitory activity on nucleases (DNases).

The present study showed that two novel proteins, p53 and p80, in splenocytes were obviously regulated by WASWE (Figure 6). The p53 expression inhibits the progression of the cell cycle or induces apoptosis ${ }^{(27,28)}$. The $\mathrm{p} 80$ protein expressed in myeloid cells is one form of the tumor necrosis factor (TNF) receptors. The TNFreceptor (p80) is involved in TNF-induced DNA fragmentation, one of the characteristic events at the early stage of apoptosis $^{(29)}$. The results in this study demonstrated that WASWE products at the indicated concentration of 0.078 $\mathrm{mg} / \mathrm{mL}$ increased intracellular protein levels of p53 and p80 (Figure 6 lanes 2, 3, and 4). The results suggested that WASWE at the lower concentration induced apoptosis of splenocytes. However, at the higher concentration $(1.250 \mathrm{mg} / \mathrm{mL})$ WASWE inhibited intracellular protein expressions of p53 and p80 (Figure 6 lanes 5, 6, and 7), suggesting that the higher concentration of WASWE inhibits apoptosis via down-regulating the expressions of p53 and p80. Obviously, the biphasic effects on intracellular protein levels of $\mathrm{p} 53$ and $\mathrm{p} 80$ existed upon treatment of extremely low and high concentrations of WASWE. The biphasic effects seem to be universal in immunologic experiments. A recent report indicates that low and high levels of $\alpha$-tocopherol exert opposite effects on IL2 expression in activated splenocytes, possibly through modulating PPAR- $\gamma$, I $\kappa \mathrm{B} \alpha$, and apoptotic pathway ${ }^{(24)}$. WASWE has been demonstrated immuno-stimulating effects via activating B lymphocytes and subsequent $\mathrm{T}$ cell proliferation in vitro at concentration of $1.250 \mathrm{mg} /$ $\mathrm{mL}^{(20)}$. However, WASWE at the lower administration concentration has little stimulation on splenocyte proliferation. This study further demonstrated that WASWE at the lower administration concentration may cause apoptosis of splenocytes in vitro. However, the regulatory mechanisms of WASWE remain to be further clarified. The present study provides preliminary evidence and suggests that the regulatory mechanisms of WASWE against apoptosis might be via inhibiting intracellular protein levels of $\mathrm{p} 53$ and $\mathrm{p} 80$. However, the specific cellular protein of $\mathrm{p} 53$ and $\mathrm{p} 80$ should be further characterized by immunoblotting analysis. Unfortunately, we could not determine other apoptosis-related intracellular proteins, including Bcl-2, Bcl- $\mathrm{X}_{\mathrm{L}}$, and Bcl-Xs, using western blotting method (data not shown). More apoptotic signals including intracellular ROS, caspase 9, 8, caspase 3 , Bax/Bcl-2 ratios, or poly (ADP-ribose) polymerase in treated cells should be further clarified ${ }^{(17)}$

Activated charcoal can absorb lower molecular weight components such as dyes ${ }^{(30)}$, phenols ${ }^{(31)}$, phenolic compounds ${ }^{(32)}$, and different drugs as well as toxic agents $^{(33)}$, including histamine ${ }^{(34)}$, acetaminophen ${ }^{(35)}$. Furthermore, the activated charcoal also adsorbs lignin and tannin colours ${ }^{(36)}$, and the natural female sex hormones $17 \beta$-estradiol, estriol and estrone ${ }^{(37)}$. Thus, these compounds described above in WASWE were possibly eliminated by the activated charcoal treatment. 
However, heat may destroy most proteins. In this study WASWE were respectively treated with activated charcoal or heat in order to characterize its anti-apoptotic components. The results from this study indicated that activated charcoal-treated WASWE at the higher concentration fully inhibited the productions of intracellular p53 and p80 (Figure 6 lane 5 versus 6). However, the productions of $\mathrm{p} 53$ and $\mathrm{p} 80$ could not be fully inhibited by heat-treated WASWE (Figure 6 lane 5 versus 7). The results suggest the anti-apoptotic effective components in WASWE may be a heat-labile component, rather than a low molecular weight pigment. Glycoprotein of Rhus verniciflua Stokes (RVS glycoprotein) has been isolated and protects splenocyte from apoptosis induced by $12-O$ tetradecanoylphorbol 13 -acetate (TPA) ${ }^{(4)}$. We have found a novel protein with a molecular weight of $313 \mathrm{kDa}$ from WASWE, which directly activates primary B-cell proliferation and subsequent $\mathrm{T}$ cell proliferation in vitro ${ }^{(20)}$. We assumed the anti-apoptotic component in WASWE is the $313 \mathrm{kDa}$ protein. However, more information on the properties concerning the anti-apoptotic components in WASWE remains to be elucidated. As the novel protein in WASWE directly activates primary B-cell proliferation and subsequent $\mathrm{T}$ cell proliferation in vitro ${ }^{(20)}$, this study further suggests that WASWE might inhibit the apoptosis of both $\mathrm{B}$ and $\mathrm{T}$ lymphocytes in splenocytes (Figure 3(B)). However, the real anti-apoptotic cell types affected by WASWE should be further clarified.

\section{CONCLUSIONS}

The present study showed that the WASWE indeed inhibited the spontaneous and DEX-induced apoptosis of murine primary splenocytes. The effective component in WASWE is suggested to be a high molecular weight, and heat-labile component. This is a potentially valuable substance for future nutraceutical or immuno-pharmacological use.

\section{ACKNOWLEDGEMENTS}

This study was supported by a research grant NSC91-2313-B-005-091 from the National Science Council, Taipei, Taiwan, Republic of China.

\section{REFERENCES}

1. Ayala, A., Xu, Y. X., Ayala, C. A., Sonefeld, D. E., Karr, S. M., Evans, T. A. and Chaudry, I. H. 1992. Increased mucosal B-lymphocyte apoptosis during polymicrobial sepsis is a Fas ligand but not an endotoxin-mediated process. Blood 91: 1362-1372.

2. Savill, J., Fadok, V., Henson, P. and Haslett, C. 1993. Phagocyte recognition of cells undergoing apoptosis.
Immunol. Today 14: 131-136.

3. Hockenbery, D. 1995. Defining apoptosis. Am. J. Pathol. 146: 16-19.

4. Lim, K. T., Lee, S. J., Heo, K. S. and Lim, K. 2003. Effects of glycoprotein isolated from Rhus verniciflua stokes on TPA-induced apoptosis and production of cytokines in cultured mouse primary splenocytes. Toxicol. Lett. 145: 261-271.

5. Itzhaki, O., Skutelsky, E., Kaptzan, T., Sinai, J., Michowitz, M., Huszar, M. and Leibovici, J. 2003. Ageing-apoptosis relation in murine spleen. Mech. Ageing Dev. 124: 999-1012.

6. Valenti, L. M., Mathieu, J., Chancerelle, Y., De Sousa, M., Levacher, M., Dinh-Xuan, A. T. and Florentin, I. 2005. High levels of endogenous nitric oxide produced after burn injury in rats arrest activated $\mathrm{T}$ lymphocytes in the first G1 phase of the cell cycle and then induce their apoptosis. Exp. Cell Res. 306: 150-167.

7. Yin, D., Zhang, Y., Stuart, C., Miao, J., Zhang, Y., Li, C., Zeng, X., Hanley, G., Moorman, J., Yao, Z. and Woodruff, M. 2006. Chronic restraint stress modulates expression of genes in murine spleen. J. Neuroimmunol. 177: 11-17.

8. Tsuchida, H., Takeda, Y., Takei, H., Shinzawa, H., Takahashi, T. and Sendo, F. 1995. In vivo regulation of rat neutrophil apoptosis occurring spontaneously or induced with TNF- $\alpha$ or cycloheximide. J. Immunol. 154: 2403-2412.

9. Wyllie, A. H. 1980. Glucocorticoid-induced thymocyte apoptosis is associated with endogenous endonuclease activation. Nature 284: 555-556.

10. Abe, M. and Thomson, A. W. 2006. Dexamethasone preferentially suppresses plasmacytoid dendritic cell differentiation and enhances their apoptotic death. Clin. Immunol. 118: 300-306.

11. Jacobson, M. D. 1998. Anti-apoptosis therapy: A way of treating neural degeneration. Curr. Biol. 8: R418R421.

12. Miller, J. B. and Girgenrath, M. 2006. The role of apoptosis in neuromuscular diseases and prospects for anti-apoptosis therapy. TRENDS Mol. Med. 12: 279286.

13. Ray, S. D., Kumar, M. A. and Bagchi, D. 1999. A novel proanthocyanidin IH636 grape seed extract increases in vivo $\mathrm{Bcl}-\mathrm{X}_{\mathrm{L}}$ expression and prevents acetaminopheninduced programmed and unprogrammed cell death in mouse liver. Arch. Biochem. Biophys. 369: 42-58.

14. Khanduja, K. L., Avti, P. K., Kumar, S., Mittal, N., Sohi, K. K. and Pathak, C. M. 2006. Anti-apoptotic activity of caffeic acid, ellagic acid and ferulic acid in normal human peripheral blood mononuclear cells: a Bcl-2 independent mechanism. Biochim. Biophys. Acta-Gen Subj. 1760: 283-289.

15. Xu, C., Shu, W. Q., Qiu, Z. Q., Chen, J. A., Zhao, Q. and Cao, J. 2007. Protective effects of green tea polyphenols against subacute hepatotoxicity induced by microsystin-LR in mice. Environ. Toxicol. Pharmacol. 
24: 140-148.

16. Guney, M., Oral, B., Karahan, N. and Mungan, T. 2007. Protective effect of caffeic acid phenethyl ester (CAPE) on fluoride-induced oxidative stress and apoptosis in rat endometrium. Environ. Toxicol. Pharmacol. 24: 8691.

17. Lim, K. T. 2005. Glycoprotein isolated from Solanum nigrum L. kills HT-29 cells through apoptosis. J. Med. Food 8: 215-226.

18. Ming, Y. L., Song, G., Chen, L. H., Zheng, Z. Z. and Chen, Z. Y. 2007. Anti-proliferation and apoptosis induced by a novel intestinal metabolite of ginseng saponin in human hepatocellular carcinoma cells. Cell Biol. Int. 31: 1265-1273.

19. Hilou, A., Nacoulma, O. G. and Guiguemde, T. R. 2006. In vivo anti-malarial activities of extracts from Amaranthus spinosus L. and Boerhaavia erecta L. in mice. J. Ethnopharmacol. 103: 236-240.

20. Lin, B.-F., Chiang, B.-L. and Lin, J.-Y. 2005. Amaranthus spinosus water extract directly stimulates proliferation of B lymphocyte in vitro. Int. Immunopharmacol. 5: 711-722.

21. Inoue, M., Suzuki, R., Koide, T., Sakaguchi, N., Ogihara, Y. and Yabu, Y. 1994. Antioxidant, gallic acid, induces apoptosis in HL-60RG cells. Biochem. Biophys. Res. Commun. 204: 898-904.

22. Dasgupta, R., Saha, I., Pal, S., Bhattacharyya, A., Sa, G., Nag, T. C., Das, T. and Maiti, B. R. 2006. Immunosuppression, hepatotoxicity and depression of antioxidant status by arecoline in albino mice. Toxicology 227: 94-104.

23. Pathak, N. and Khandelwal, S. 2006. Oxidative stress and apoptotic changes in murine splenocytes exposed to cadmium. Toxicology 220: 26-36.

24. Hsieh, C.-C., Huang, C.-J. and Lin, B.-F. 2006. Low and high levels of $\alpha$-tocopherol exert opposite effects on IL-2 possibly through the modulation of PPAR- $\gamma$, $\mathrm{I} \kappa \mathrm{B} \alpha$, and apoptotic pathway in activated splenocytes. Nutrition 22: 433-440.

25. Li, L., Krajewski, S., Reed, J. C. and Choi, Y. S. 1997. The apoptosis and proliferation of SAC-activated B cells by IL-10 are associated with changes in $\mathrm{Bcl}-2$, Bcl-X $\mathrm{L}_{\mathrm{L}}$, and Mcl-1 expression. Cell Immunol. 178: 3341.
26. Forrest, V. J., Kang, Y. H. and McClain, D. E. 1994. Oxidative stress-induced apoptosis prevented by trolox. Free Radic. Biol. Med. 16: 675-684.

27. Ikeda, M., Okamoto, I., Tamura, K., Satoh, T., Yonesaka, K., Fukuoka, M. and Nakagawa, K. 2007. Down-regulation of survivin by ultraviolet $\mathrm{C}$ radiation is dependent on p53 and results in $\mathrm{G}_{2}-\mathrm{M}$ arrest in A549 cells. Cancer Lett. 248: 292-298.

28. Tian, C., Lv, D., Qiao, H., Zhang, J., Yin, Y. H., Qian, X. P., Wang, Y. P., Zhang, Y. and Chen, W. F. 2007. TFDP3 inhibits E2F1-induced, p53-mediated apoptosis. Biochem. Biophys. Res. Commun. 361: 20-25.

29. Higuchi, M. and Aggarwal, B. B. 1993. P80 form of the human tumor necrosis factor receptor is involved in DNA fragmentation. FEBS Lett. 331: 252-255.

30. Iqbal, M. J. and Ashiq, M. N. 2007. Adsorption of dyes from aqueous solutions on activated charcoal. J. Hazard. Mater. B139: 57-66.

31. Mukherjee, S., Kumar, S., Misra, A. K. and Fan, M. 2007. Removal of phenols from water environment by activated carbon, bagasse ash and wood charcoal. Chem. Eng. J. 129: 133-142.

32. Soto, M. L., Moure, A., Dominguez, H. and Parajo, J. C. 2008. Charcoal adsorption of phenolic compounds present in distilled grape pomace. J. Food Eng. 84: 156163.

33. Vale, A. 2007. Reducing absorption and increasing elimination. Medicine 35: 560-561.

34. Thomas, S. H. L. 2007. Antihistamine poisoning. Medicine 35: 592-593.

35. Spiller, H. A. and Sawyer, T. S. 2007. Impact of activated charcoal after acute acetaminophen overdoses treated with N-acetylcysteine. J. Emerg. Med. 33: 141144.

36. Mohan, S. V. and Karthikeyan, J. 1997. Removal of lignin and tannin colour from aqueous solution by adsorption onto activated charcoal. Environ. Pollut. 97: 183-187.

37. Fuerhacker, M., Durauer, A. and Jungbauer, A. 2001. Adsorption isotherms of $17 \beta$-estradiol on granular activated carbon (GAC). Chemosphere 44: 1573-1579.

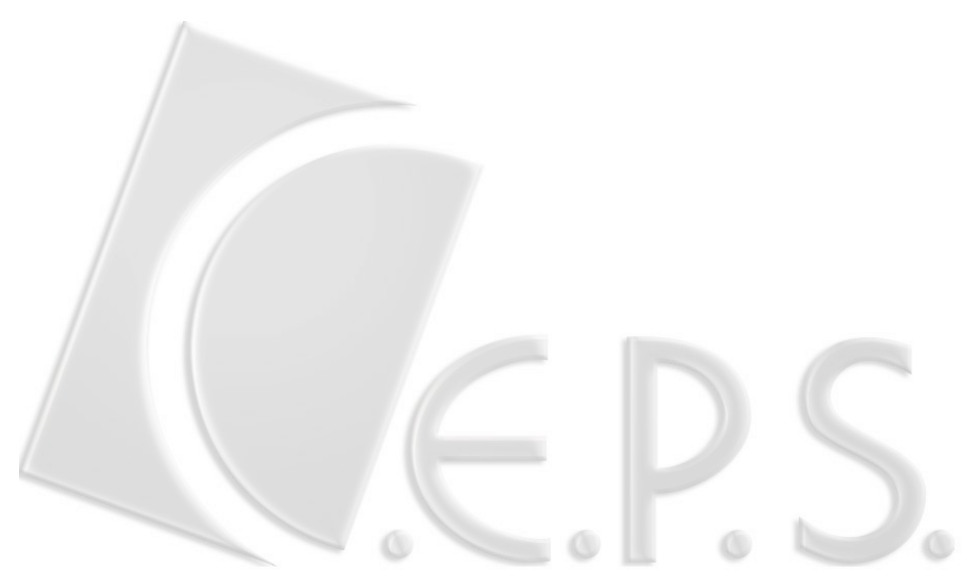

